\title{
THE COST-BENEFIT ANALYSIS OF THE TWO NEIGHBOURLY AGREEMENTS WITH BULGARIA AND GREECE: THE LINGUISTIC PERSPECTIVE
}

\author{
Elka JACHEVA-ULCHAR, \\ Institute for Macedonian Language "Krste Misirkov"
}

\begin{abstract}
In this article we refer to the agreement/treaty of the Republic of Macedonia with the Republic of Greece (signed in June 2018) and the Republic of Bulgaria (August 2017), with special emphasis on the treatment of the Macedonian minority whose recognition or non-recognition in these two neighboring countries depends on recognition of the Macedonian language, the Macedonian toponyms, as well as when and in what way the adjective Macedonian will be used. In this sense, both the agreement and the treaty are unfavorable for Macedonia because both of them strike at the basic identity and national features: the name of the country and the Macedonian language. While both neighboring countries in the negotiating platform for the agreements have included all their available capacities and professional staff (we have in mind lawyers, historians, linguists, diplomats, etc.) in Macedonia both the agreement/treaty are the result of a closed circle of politicians, without the involvement to the scientific and professional public, which ultimately contributed to the signing of such asymmetric agreements to the detriment of the Republic of Macedonia.
\end{abstract}

Keywords: Macedonia, Greece, Bulgaria, agreement, Macedonian language, toponyms

\section{Introduction}

As the time distance from the signing of the two bilateral agreements increases, it becomes clearer to even the most inexperienced and least familiar observers that the documents signed by the Republic of Macedonia, first with the Republic of Bulgaria and then with the Republic of Greece, have brought much more damage to the Macedonians and the Macedonian state than benefits. The official narrative in both cases argued that solution of the bilateral disputes with the neighbors would open the EU perspectives of the Macedonian state, which would immediately reflect on country's economic prosperity and citizens' wellbeing. A few years later, the country is still knocking on the EU's door in vain, now due to the Bulgarian veto as of December 2020.

In sum, the basic premise of this article is that the expected and promised benefits de facto have turned into an irreparable damage and a serious blow to the Macedonian nation and state. Both the Friendship Treaty (2017) and the Prespa Agreement (2018) seem to have been drafted

1 Contact address: elka.jaceva.ulcar@gmail.com 
with an aim to erase the basic identity features of a nation: i.e., its name, culture and cultural heritage, history and folklore, and language. This article pays specially attention to the impact of these agreements on the linguistics and language rights, i.e., it focuses on an issue that has not been elaborated so far. In addition, we make anoverview of the treatment of the Macedonian minority as it is envisagedin these two agreements. This issue goes far beyond the classical notion of collective/minority rightsprotection because it has become a significant part of the deals: i.e., the very recognition of the existence of a distinct Macedonian language, the Macedonian toponyms, but also the use of the adjective Macedonian directly depend on the (mis)recognition and/or (non)recognition of these minority groups both in Greece and Bulgaria. In other words, the classical minority issue has turned into questioning of the existence of the constituent nation of the modern Macedonian state.

\section{Analusis of the Prespa Agreement between Republic of Macedonia and Republic of Greece}

The signing of the so-called Prespa Agreement (2018), ${ }^{2}$ which paved the way to the change the name of the Republic of Macedonia into the Republic of North Macedonia (in 2019), was far more than simple renaming of astate entity. This agreement, among other things, caused a certain imbalance in the Slavic studies, and especially against the background of dialectology, which consequently reflected (and is reflected) on the dialectological atlases as all-Slavic decades-old macro-projects. ${ }^{3}$ Namely, with this agreement, the linguistic spread of the Macedonian language was reduced; and b) an intrusion into the word formation of the Macedonian language was made.

a) The reduction of the linguistic spread of the Macedonian language is a consequence of the renunciation of the Macedonian minority in Aegean Macedonia, which according to this Agreement is the 'real' Macedonia, which occupies an area in northern Greece. The renunciation of the Macedonian minority in Greece, which under this phrase, of course, does not explicitly appear in the Prespa Agreement, one coulddetect in the perfidiously crafted Article 4 which reads:

1. Each of the Parties hereby undertakes and solemnly declares that no provision of its Constitution, as in force or as amended in the future, may or may not be construed as representing or at any time constituting grounds for claim to any area that is not within its existing international borders.

2. Each of the Parties undertakes not to make or endorse any irredentist statements and will not endorse any such statements made by those claiming to act in the name or interest of one of the Parties.

3. Each Party hereby undertakes and solemnly declares that no provision of its Constitution, as in force or as amended in the future, may or may not be construed as constituting or at

\footnotetext{
2 Its official title reads Final Agreement for the settlement of the differences as described in the United Nations Security Council Resolutions 817 (1993) and 845 (1993), the termination of the Interim Accord of 1995, and the establishment of a Strategic Partnership between the Parties.

3 After the signing of the Prespa Agreement, the dialects in Aegean Macedonia, from some Slavic countries and academies, especially from Bulgaria, began to be problematized and denied as Macedonian.
} 


\section{Secururity}

any time constitutes grounds for interference with the internal affairs of the other Party, in any form or by any reason, including the protection of the status and rights of any person other than its nationals.

A careful analysis of the paragraph 3 of this article displays the following: the weaker side of the Agreement undertakes (Sic! Solemnly, what hypocrisy?!) an obligation "not to interfere in the internal affairs of Greece and to give up the protection of the rights of any persons who are not its citizens" (meaning, the Macedonians in the Aegean Macedonia). By committing itself to this, Macedonia hasde facto agreed with the Greek position that there is no Macedonian minority in Greece. By doing so, it implicitly is giving up the Macedonian minority as a bearer of the Macedonian language and language rights that steam from it. In other words, it means giving up all the Macedonian dialects on the other side of the state border with the Republic of Greece on the axis east - west, ${ }_{1}^{4}$ which will give the Macedonian language for the first time (and below we will see for the second time) the 'exclusivity' to be the only European language whose spread is limited within a single state (whose identity is disputed anyway). Apart from the Aegean dialects, the Macedonian government led by Prime Minister Zoran Zaev, officially and irrevocably gave up the Macedonian toponyms in northern part of Greece where the Macedonians have been living for centuries.

Where this claimcome from? Namely, paragraph 4 of Article 8 of the Prespa Agreement reads that "each of the Parties shall adhere to the recommendations of the United Nations Conference on the Standardization of Geographical Names regarding the use of official geographical names and toponyms on the territory of the other Party, giving priority to the use of endonyms instead of exonyms. "In order to clarify the matters, let us first explain what an endonymis and what an exonym is. An endonym is a toponym, i.e., the official name of a place used within one country, while an exonym is a toponym that a country uses as a name for a city, state, and is different from the original name in another country, i.e. different from the endonym. Thus, for example, in the Macedonian language the Greek city of Thessalonikiis called Solun (the same applies to the other Slavic languages too). Also, the Slovenians call Vienna - Dunaj, the Serbs and Croats call the same city Bech, etc. Hence Thessaloniki, Vienna, Dunaj and Bech are exonyms for the endonyms: Thessaloniki, i.e. Vienna. And here is the first problem, aside from the fact that until the signing of the Prespa Agreement, the two terms "endonyms" and "exonyms" had not been even mentioned at all by the negotiators, in any context. Namely, what will for the Macedonians be an endonym or exonym is historically and culturally determined. In the aftermath the Balkan wars (1912/1913), along with the tectonic demographic, political and cultural changes that took place in Aegean Macedonia, the Greek authorities undertook an action of systematic and enforced change of the Slavic names and their replacement with Greek names - not only of the geographical cites but also of the population (Observer, 2018).

4 Here we would like to point out that in the dialectology department at the Institute of Macedonian Language "Krste Misirkov", almost all dialectologists in their master's and doctoral theses as a subject of elaboration and analysis have a speech from the Aegean dialect system. 


\section{Seceururity}

One may pose the question of the underlying reason for such a policy run by the Greek state. The answer probably lies in the fact that any government knows that toponyms, as the oldest lexical units in every language, witnessed the spread of a nation over a certain territory. Thus, the German linguist Max Vasmer in his study "Slavs in Greece" (1941), published in Berlin, based on the analysis of about 2,000 toponyms on the territory of Greece. He discovered Slavic linguistic elements, and consequently concluded that the Slavic language spread reached even to the Peloponnese. The Slavic element was so present in the Greece mainland that even the famous Balkanist Zbigniew Gołąbin one of his studies (1989) argues that "... modern Greeks are biologically much closer to the Slavs than to the ancient Greeks. Today's Greeks are just Hellenized Slavs, who were Hellenized by the adoption of Christianity." He cited the statement of Constantine Porphyrogenitus claiming that "the whole country was converted (meaning Greece) and became barbaric". Hisfindings supported the onesearlier elaborated in "History of the Morea Peninsula in the Middle Ages" by Jakob Philipp Fallmerayer (1836), which proved that the Greeks were wiped out and replaced by Slavic tribes, without, of course, bypassing the studies of Slavic oikonym in Greece by Max Vasmer and PhaedonMalingudis (1981).

The biggest replacement of the Slavic toponyms with Greek ones took place in 1926. It was then when the so-called 'spontaneous changes' of the names of the settlements was made official through the adoption of a decree. Itwas the beginning of an enforced Hellenization of everything non-Greek on the territory of Aegean Macedonia. But despite the almost hundred-year-old Greek assimilation policy, the Macedonians, especially the middle-aged generation, and mostly those who live in the mountains, manage to preserve their mother tongue in the most unfavorable conditions. From one of our field surveys conducted in early 2013, in the Lerin and Voden regions, we concluded that the Slavic micro-toponyms in these areas are still in use, despite the fact that the younger generation of Macedonians have little or no knowledge of the Macedonian language.

The second problem that arises with the summoning of the above-mentioned Commission for Standardization of Geographical Names at the United Nations is that the Macedonian government has not established it at all. Thus, the Greek side used this fact in the sense that - if Macedonia had such a commission, she would probably have had a list of exonyms sent to the UNGEGN (United Nations Group of Experts on Geographical Names), in which the Macedonian names of the settlements in Northern Greece would be listed. Thus, despite the fact that the exonym Solun is used by almost all the South Slavic languages, only for the Macedonians the Prespa Agreement imposed the obligation to use the Greek endonym Thessaloniki. ${ }^{5}$

b) Despite the claims of the Macedonian negotiators with Greece, i.e., Prime Minister Zaev and the then Minister of Foreign Affairs Nikola Dimitrov, that the use of the adjective Macedonian was guaranteed for free use, soon it became clear that this adjective would be used selectively and inconsistently. For that purpose, the Macedonian Ministry of Foreign Affairs prepared Guidelines for the use of the adjective Macedonian. This 'guideline' shows that Macedonian is "allowed to be

5 Of course, this does not refer only to the name of the city of Solun, but to the names of all settlements in Aegean Macedonia. For example: Voden with the Prespa is confirmed as Edessa, Lerin - as Florina, Kukush - as Kilkis, Kutlesh as Vergina, etc. 
used" only in cases where the adjective refers to the people, i.e., to something that refers to the ethnic Macedonians (such as Macedonian literature, Macedonian language, Macedonian theatre and art); everything else that refers to the state, as well as in trade and branding, is expressed (according to the author of these lines) by "a new genitive in the Macedonian language", which reads "... of the Republic of North Macedonia". This is because a distinction should be made between the state of Macedonia and the region of Macedonia (i.e., the Greek region). In reality, it means that the Greek side holds the exclusive right to use the brand "Macedonia/Macedonian".

The use of the neo-Macedonian genitive of the Republic of North Macedonia is forced due to the Macedonian side's intention to avoid the natural and spontaneous word formation i.e., North Macedonianat all costs, and not only in Macedonian, but also in other world languages. The warnings of the Macedonian linguists that any adjective must not be added between the nouns the Republic and Macedonia were in vain. Linguistically, the noun phrase consisting of an adjective and a noun in the formation of an adjective entails a formation of a complex adjective, which occurs with the merging of the first (adjective) with the second component (noun) in a word form. The MediaGuidelines (Ministry of Foreign Affairs 2019) wereissued by the government and translated into English. Allegedly, they were sent to the highest state institutions around the world, as well as to the foreign media, as if they would be obliged by an internal governmental act.

The practice, however, shows that the battle with the non-use of the adjective North Macedonian is lost, because no one, not even the world-famous linguist is allowed to make political intrusions into any language'ssystem. Only from these above-mentioned points, which directly affect the Macedonian language, it can be seen that the unwanted change of the name of the country did not only lead to this alteration, but also caused the change of the names of a huge number of institutions that used to have the adjective Macedonian in their official names. The names of the institutions such as the Institute for Macedonian Language, Macedonian National Theater and Macedonian Radio-Television have remained unchanged for now. According to the Prespa Agreement, the Macedonian Academy of Sciences and Artsis also to be renamed intothe Academy of Sciences and Arts of the Republic of North Macedonia, preserving the acronym MANU. Also, the Macedonian Opera and Ballet became the National Opera and Ballet, and the Macedonian Philharmonic became the Philharmonic of the Republic of North Macedonia, the Macedonian Post is renamed National Post, etc. MANU still bears the name it gotduring its establishment in 1967, mostly because the vocal opposition of the Presidency of MANU, led by its new President, highly esteemed professor LjupcoKocarev (MKD 2021).

\section{Analysis of the Friendship Treaty with the Republic of Bulgaria}

The Prespa agreement proved to be just the small obstacle on the way to EU, as the Friendship Treaty with the Republic of Bulgaria $(2017)^{6}$ appears to contain much greater demands, also with respect to the Macedonian language. The Treaty was an object of severe criticism even before its

6 The full name of the agreement reads Treaty on friendship, good neighbourliness and cooperation between the Republic of Macedonia and the Republic of Bulgaria. 
signing. Especially, many Macedonian historians were vocal and anticipated the hurdles during the implementation of such a vague and asymmetric treaty.

For the linguists, the most controversial part of this agreement is the content of Article 11, especially paragraph 5. It practically renounces Bulgaria's Macedonian minority. Interestingly, in the autumn of 2020, the European Parliament adopted Resolution in which the Bulgarian government was called to to implement nearly 80 verdicts of the European Court of Human Rights, including four from Macedonian organizations such as OMO llinden - Pirin. Bulgaria was also called to end all forms of hate speech and violence against the minorities (Republika 2020).

After the signing of the Prespa Agreement and having sensed the lenient invertebrate foreign policy pursued by the Macedonian politicians towards the southern neighbor, Bulgaria got encouraged, coming up with new demands that do not appear in the Friendship Treaty. In October 2019, the Bulgarian Parliament adopted a declaration, in which two points refer exactly to the Macedonian language. The Declaration, among other things, states: "... nowhere in the EU documents should the "Macedonian language" appear, i.e., if it must, then use the term "official language of the Republic of North Macedonia". If, as it is stated, "there is an absolute necessity to use the term 'Macedonian language' in EU documents and positions, to clarify with an asterisk in the footnote that it is "in accordance with the Constitution of the Republic of North Macedonia" (...) and that "it should be clear that the language norm that has been declared a constitutional language in the Republic of North Macedonia is related to the evolution of the Bulgarian language and its dialects with its codification in 1944."; 2. "(..) the renunciation of the support or the request for recognition of the Macedonian minority in the Republic of Bulgaria" (BIRN 2019).

The Macedonian public and the Macedonian national institutions reacted again to this request from the Bulgarian side, but the current Macedonian politics remained tongue-tied even when a book titled "On the Official Language of the Republic of North Macedonia" appeared in the Bulgarian Academy of Sciences (BAS) in spring 2020. In fact, the existence of the Macedonian language is clearly denied, and through lies, insinuations, twisting of historical facts it is qualified it as a "Western Bulgarian dialect", and an artificial linguistic construct formed due to the blessing of "the dictator Tito".The first responsecame from the Institute of Macedonian Language (Antropol 2020), while later the Macedonian Academy of Sciences and Arts (MANU) and all the other relevant institutions published the monograph entitled "Macedonian language - continuity in space and time" (MANUet al 2020).

The provocations from the Bulgarian side have not subsided, and have become a daily routine, especially after the adoption of the European Resolution on the existence of the Macedonian minority in Bulgaria (Pavlovska 2020). Shortly before the ministerial meeting in Brussels, a non-paper circulated in the Macedonian public (SDK 2020), which is considered to be a proposal from the EU presidency, Germany, for an annex to the Friendship Treaty between Macedonia and Bulgaria. According to the annex to the Agreement, the Macedonian language should have the suffix "according to the Constitution", i.e. it would mean that the Macedonian language exists only from 1945. In other words, it is expected for Macedonia to give up its rich ten-century literary and oral tradition. Also, the annex proposes a clarification of Article 8, which would imply that 
Macedonia gives up any idea of Macedonian minority in Bulgaria (following the example of the Prespa Agreement with Greece). The consequence is that the Macedonian language is shortening its language span and its eastern state border. The Macedonian government remained silent until Prime Minister Zoran Zaev gave an 'unfortunate' interview to the Bulgarian media BGNES (360 stepeni 2020), after which, under public pressure, and mostly under pressure from a number of state institutions, hewas enforced to abandonany intention to give in to the Bulgarian demands, which de facto blackmailed the Macedonian sideon the eve of the expected opening of the negotiations for Macedonia'smembership in the EU. According to Prime Minister Zaev, it has been announced that the Republic of Bulgaria, taking example from the Republic of Greece, expounds the adjective 'Macedonian' and insists on its deletion. So far, the Macedonian public experiences a déjà vu sensation with the strong veto position of Sofia regarding Macedonia's progress to EU.

\section{Conclusion}

The article argues that both agreements in focus weight heavily on the basic identity traits of the Macedonian nation: i.e., the name of the country, the name of the language and its existence, culture, history (national and spatial), the folklore and other forms of non-material cultural heritage. Hence there is a general impression in the Macedonian public that they do not resolve the bilateral issues, but to the contrary: they make the Macedonian Question - existing on the historical stage for more than a century - even more intricate. In essence it boils down to the key question: Do Macedonians and the Macedonian language exist?

A nation born from inexistence, ex nixilo, cannot not exist. It is utterly improper and unreasonable to negate the existence of any nation in the $21^{\text {st }}$ century but it is exactly what the Macedonian nation has been faced with despite its almost a centennial statehood, and social life administered by a standard and standardized Macedonian language, the foundation of which was set as far back as 1903 by Krste Petkov Misirkov in his scientific study On The Macedonian Affairs.

The Macedonian language is a separate entity within the large Slavic language family, as well as within the Balkan lingual alliance, with its own characteristics and traits intrinsic only to itself. To the Macedonians - and to all the nations in general - the Macedonian language is an inseparable part of their identity and any interference is interpreted as an attack aiming to negate and vandalize the language.

Furthermore, for both the Bulgarian Agreement from August 2017 and the Prespa Agreement signed in June 2018 there is a common denominator, which brings them together: both agreements suffer from serious procedural and constitutional irregularities and failures. Both were negotiated within a closed circle, with no involvement of the academic, expert and professional public. They made the national institutes formed just years after the first constitution of the Macedonian state (enacted after World War II, in 1946) to become obsolete and to fall into the absurdity of their existence. They were formed to study and preserve the language, history, culture and folklore as basic identification pillars of the Macedonians. Now they have lost their raison d'être. Bearing in mind that the general public was and still is kept in ignorance about the negotiation processes among Skopje, Athens and Sofia (let alone Brussels and other power centers), the Macedonian 
people remains a statist in the drama. It has been deprived a status of a self-aware actor in the decision-making process which deals with its own existence and in the international relations.

As the article proves, both agreements serve no national and vital interests of the Macedonian side, which means that they are asymmetric and detrimental not only for the respective nation but also for the regional peace and stability.

\section{References}

1. 360 stepeni (2020), „Интервју на Заев за БГНЕС: Испративме документ дека немаме територијални претензии, нема да се мешаме во внатрешните работи и немаме побарувања за малцинствата“" [Zaev's interview for BGNES: We sent a document that confirms that we have no territorial claims, won't interfere in the internal affairs and we have no demands regarding the minorities], 25 November, online https://360stepeni. mk/video-intervju-na-zaev-za-bgnes-isprativme-dokument-deka-nemame-teritorijalni-pretenzii-nema-da-se-meshame-vo-vnatreshnite-raboti-i-deka-nemame-pobaruvana-za-maltsinstva/(accessed on 10.12.2020).

2. Antropol (2020), "Институтот „Крсте Мисирков“ до БАН: Македонскиот јазик е реалност, а не југозападна писмено-регионална форма на бугарскиот јазик" [Institute "Krste Misirkov" addresses BAS: The Macedonian language is reality and not a south-west literary-regional form of the Bulgarian language], 11 May, online https://antropol. $\mathrm{mk} / 2020 / 05 / 11 /$ institut-krste-miriskov-do-ban/(accessed on 10.12.2020).

3. БАН (2020), ЗА ОФИЦИАЛНИЯ ЕЗИКНА РЕПУБЛИКА СЕВЕРНА МАКЕДОНИЯ[0n the Official Language of the Republic of North Macedonia], online https://drive.google.com/ file/d/1yFZM_CRY539B9d64SVg5RT7TQLaX71FK/view(accessed on 10.12.2020).

4. BIRN (2019), "Bulgaria Sets Tough Terms for North Macedonia's EU Progress", 10 October, online https://balkaninsight.com/2019/10/10/bulgaria-sets-tough-terms-for-northmacedonias-eu-progress/(accessed on 10.12.2020).

5. Fallmerayer Jacob Philipp (1836), Geschichte der Halbinsel Morea während des Mittelalters, vol. 2, Stuttgart.

6. Final Agreement for the settlement of the differences as described in the United Nations Security Council Resolutions 817(1993) and 845 (1993), the termination of the Interim Accord of 1995, and the establishment of a Strategic Partnership between the Parties (2018), online https:// vlada.mk/node/17422 (accessed on 10.12.2020).

7. Gołąb Zbigniew (1989), "The language of the first Slavs in Greece: VII-VIII Centuries“,Appendices, XIV / 2, Skopje: MANU.

8. Malingudis Phaedon (1981), Studienzu den slavischenOrtsnamenGriechenlands, Wiesbaden: Franz Steiner VerlagGmbh.

9. MANU et al. (2020), Македонскиот јазик - континуитет во простор и време [The Macedonian Language - Space and Time Continuity], online http://manu.edu.mk/wp-content/ uploads/2020/07/Makedonskiot-jazik_kontinuitet-vo-prostor-i-vreme_kolektivna-monografija.pdf(accessed on 10.12.2020). 
10. Ministry of Foreign Affairs of North Macedonia (2019), Prespa Agreement-Media Guidelines, 22 February, online https://mfa.gov.mk/en/page/8/post/1695/prespa-agreement-media-guidelines(accessed on 10.12.2020).

11. МКД (2021), „МАНУ не го дава името, Владата вели дека ќе мора да се прекрсти“ [MANU does not give the name, the Government says that it will have to be renamed], 22 February, onlinehttps://www.mkd.mk/makedonija/politika/manu-ne-go-dava-imetovladata-veli-deka-kje-mora-da-se-prekrsti(accessed on 10.12.2020).

12. Observer (2018), "Промена на топонимите во Егејскиот дел од Македонија“ [Toponyms Change in the Aegean part of Macedonia], 22 June, online https://opserver.mk/izdvojuvame/promena-na-toponimite-vo-egejskiot-del-od-makedonija-video/ (accessed on 10.12.2020).

13. Павловска Јасминка (2020), „Бугарската позиција не може веќе да се брани, но без меѓународен притисок таа нема да се промени" [The Bulgarian position is impossible to defend any more, but without any international pressure it will not change either], Нова Македонија, 2 December, online https://www.novamakedonija.com.mk/makedonija/politika/\%D0\%B1\%D1\%83\%D0\%B3\%D0\%B0\%D1\%80\%D1\%81\%D0\%BA\%D0\%B0\%D1\%82\%D0 \%B0-\%D0\%BF\%D0\%BE\%D0\%B7\%D0\%B8\%D1\%86\%D0\%B8\%D1\%98\%D0\%B0-\%D0\%BD\%D0\%B5-\%D0\%BC\%D0\%BE\%D0\%B6\%D0\%B5-\%D0\%B2\%D0\%B5\%D1\%9C\%D0\%B5$\% \mathrm{D} 0 \% \mathrm{~B} 4 \% \mathrm{D} 0 \% \mathrm{~B} 0-\% \mathrm{D} 1 \% 81 \% \mathrm{D} 0 \% \mathrm{~B} 5 /$ (accessed on 10.12.2020).

14. Republika (2020), "EU criticism of Bulgaria reopens the issue of its Macedonian minority", 9 October, online https://english.republika.mk/news/macedonia/eu-criticism-of-bulgaria-reopens-the-issue-of-its-macedonian-minority/(accessed on 10.12.2020).

15. SDK, „Бугарија во Берлин прифатила нон-пејпер за македонскиот јазик за да почнат преговорите на Македонија со ЕУ, па се пишманила" [Bulgaria accepted non-paper in Berlin to start Macedonia's negotiations with the EU, afterwards changed its mind], 20 November 2020, online https://sdk.mk/index.php/makedonija/bugarija-vo-berlin-prifatila-non-pejper-za-da-pochnat-pregovorite-na-makedonija-so-eu-pa-se-pishmanila/ (accessed on 10.12.2020).

16. Treaty on friendship, good neighbourliness and cooperation between the Republic of Macedonia and the Republic of Bulgaria (2017), online https:/vlada.mk/sites/default/files/dogovori/ Dogovor_Za_Prijatelstvo_Dobrososedstvo_Sorabotka_Megju_Republika_Makedonija_I_Republika_Bugarija.pdf (accessed on 10.12.2020).

17. Vasmer Max (1941), Die Slaven in Griechenland, Verlag der Akademie der Wissenschaften: Berlin, online http://macedonia.kroraina.com/en/mv/index.html. 